https://dx.doi.org/10.4314/ijs.v21i3.1

Ife Journal of Science vol. 21, no. 3 (2019)

\title{
MORPHOMETRIC CHARACTERISTICS, FOOD OF TARPON ATLANTICUS AND WATER QUALITY TRENDS IN THE OGUDU CREEK LAGOS, NIGERIA
}

\author{
Emmanuel, B. E.* and Ross, Y. R. \\ Department of Marine Sciences, Faculty of Science, University of Lagos, Akoka - Yaba, Lagos. \\ *E-mail of corresponding author: monetemi@gmail.com \\ (Received: $10^{\text {th }}$ November, 2017; Accepted: $2^{\text {nd }}$ August, 2019)
}

\section{ABSTRACT}

\begin{abstract}
The morphometric characteristics and the food of Tarpon atlanticus as well as the water quality trend in Ogudu Creek, Lagos, Nigeria, where the fish was caught, were studied between January and May 2011. The air temperature ranged between 24 and $32^{\circ} \mathrm{C}$ with mean value of $30.5^{\circ} \mathrm{C}$ and surface temperature between 28.5 and $33.5^{\circ} \mathrm{C}$ with mean value of $31.0^{\circ} \mathrm{C}$. The $\mathrm{pH}$ varied from being alkaline (8.3) and acidic (3.97) with mean value of 6.13. Salinity at lowest was $(12.80 \%$ ), the highest $(24 \% 0)$ with mean value of $18.4 \%$ while dissolved oxygen ranged between $4.3 \mathrm{mg} / \mathrm{L}$ and $8.6 \mathrm{mg} / \mathrm{L}$ with mean value of $6.45 \pm 1.01 \mathrm{mg} / \mathrm{L}$. The total length of specimens ranged from $11.0-25.9 \mathrm{~cm}$ (Standard length $5.1-16.0 \mathrm{~cm}$ ) and weight $1.97-76.93 \mathrm{~g}$. The specimens showed a unimodal distribution. The length - weight relationship for the combined sexes exhibited a negative allometric growth (0.911). The fish stomach had fish parts, fish scales and unidentified mass. The condition factor ranged from 0.475 and 1.046. The morphometric analysis exerted a highly positive correlation among the body parts; the total length and body weight $(r=0.92)$, total length and standard length $(r=0.92)$. The results of the present study also suggest that $T$. atlanticus living in the same place showed morphological divergence.
\end{abstract}

Keywords: Stomach content, Condition factor, Fish length, Morphology, Unimodal distribution

\section{INTRODUCTION}

Fish is a protein source which helps in the repair of worn out tissues and replacement of dead cells in human beings. The Atlantic Tarpon (Tarpon atlanticus) is a tropical/sub-tropical and warm temperate fish abundant in the Atlantic Ocean; in the Eastern Atlantic area of Africa, which extends from Mauritania to Angola concentrating around the Gulf of Guinea zone where the thermocline is always close to the surface (Schneider, 1990). In the Western Atlantic, the species occurs from Nova Scotia to Brazil although more abundant in the warmer coastal waters of Florida, Gulf of Mexico and West Indies (Irvine, 1947; Fischer et al, 1981; Whitehead et al, 1984). According to Zerbi (1999), Tarpon (Megalops atlanticus) are widely distributed in warm temperate, subtropical and tropical waters ranging from Nova Scotia to Argentina in the western Atlantic Ocean, from Senegal to Angola in the eastern Atlantic Ocean, and proximate to Panama Canal terminus in the eastern Pacific Ocean.

T. atlanticus is a carnivorous species as stated by Zale and Merrifield (1989). Bond (1979) reported that such species including pikes and sharks are equipped with large mouths that mark them as predators for large prey which may be swallowed whole. Most piscivorous species according to Lagler et al., (1962) have developed adaptation for predatory habit in their skull bones essentially for increasing the gape of the mouth. Both Tarpon atlanticus and the ten pounder- Elops sp. have gular plates in their lower jaws on the underside of their head. The gular plate is used for crushing preys that are not consumed whole (Bond, 1979).

The studies of food and feeding habits of fishes have been carried out by various workers (Munro, 1967; Fagade and Olaniyan, 1973; Kusemiju and Olaniyan, 1977; Ekpo, 1982). Ugwumba (1984) reported that Elops lacerta fed mostly on fish, crustaceans, insects and gastropods. Piscivorous fishes are known to consume a lot of their prey when they are most available. Adult Tarpon as revealed by Whitehead and Vergara (1978), Hureau, (1984) and Chaverri-Charcon (1994) feed on fishes especially those forming schools like sardines, mugilidae, cichlidae and invertebrates including shrimps and crabs. The juveniles feed on zooplankton, insects and small fish.

The stomachs of piscivorous are thickened, muscularised and have gastric acidity of $\mathrm{pH}$ 2.4- 
3.6 to aid protein digestion (Largler et al., 1962). However, the intestine is short in contrast to the long, coiled intestines of the herbivores like tilapia. In other fish species (e.g. minnows or parrot fishes), the stomach is lacking, and the oesophagus empties directly into the intestine (Bond, 1979).

The study of age and growth of many fish species have been carried out by many workers but in the tropics, growth interpretation on the hard parts is difficult as there are no marked seasons that cause cessation of growth as evident in the temperate regions. However, Bayagbona (1969), Kusemiju (1973), Fagade (1974), Ezenwa and Kusemiju (1981) and Ugwumba (1984) have used various methods to age tropical fishes with some levels of success. Fagade (1974) carried out age determination in Sarotherodon melanotherodon in Lagos Lagoon with emphasis on environmental and physiological basis of growth marking in the tropics. On the other hand, Ezenwa and Kusemiju (1981) used the dorsal spine of the catfish Chrysichthys nigrodigitatus for the determination of the age of the species.

Observation made by Fischer et al (1981) indicated that $T$. atlanticus moved into open waters to spawn late April to August and passed through a leptocephalus larval stage before metamorphosing into juvenile stage (Crabtree et al., 1995). Tarpon atlanticus as observed by Crabtree et al (1995) is dimorphic with the females growing larger than the males.

In Nigeria, this species plays a major role in the commercial artisanal fisheries. Not much work has been done on the biology of this species in Nigeria. Anyanwu, (2004) carried out work on the biology, fishery and culture potentials of the Atlantic Tarpon in coastal waters of Western Nigeria. It is necessary to fully analyze and document the aspects of $T$. atlanticus food and feeding habit in relation to its occurrence in the wild. Therefore, this study is aimed at examining the occurrence, morphometric characteristics and food preference based on the different sizes of Tarpon atlanticus in Ogudu Creek Lagos Lagoon, Nigeria.

\section{MATERIALS AND METHODS Description of the Study Area}

Ogudu Creek is adjacent and connected to the Lagos Lagoon around Oworonsoki. The Lagos Lagoon is the largest brackish water body of the lagoon systems south western, Nigeria with an area of $208 \mathrm{~km}$ (Webb, 1958; Hill \& Webb, 1958). The Lagos Lagoon extends from the coast of Lagos about $37 \mathrm{~km}$ North and about $48 \mathrm{~km}$ East where it narrows and continues as the Lekki Lagoon. It stretches for about $257 \mathrm{~km}$ from Cotonou in the Republic of Benin to the Western edge of the Niger Delta (FAO, 1969). It is linked with the Atlantic Ocean (Gulf of Guinea) via the Lagos Harbor which serves as the major outlet of freshwater from the lagoon system during the rainy season.

The lagoon is situated in the rain forest belt of Nigeria which experiences two different seasons, i.e. the wet season (May - October) and dry season (November - April) (Fagade, 1969). Two peaks of rainfall linked with excessive floods are generally associated with the major peak in June and a lesser peak in September. The Lagos Lagoon has a diurnal tidal system (two high tides and two low tides each day). At high tide, sea water enters the lagoon from the Atlantic Ocean via the harbor and five cowrie creeks, while the water recedes at low tide (Fagade, 1969). Being open all through the year, the brackish environment is therefore a consequence of the influence of tidal sea water incursion and freshwater discharge from adjoining creeks and rivers such as Badagry, Majidun, Ogudu, Yewa, Ogun and Osun. 


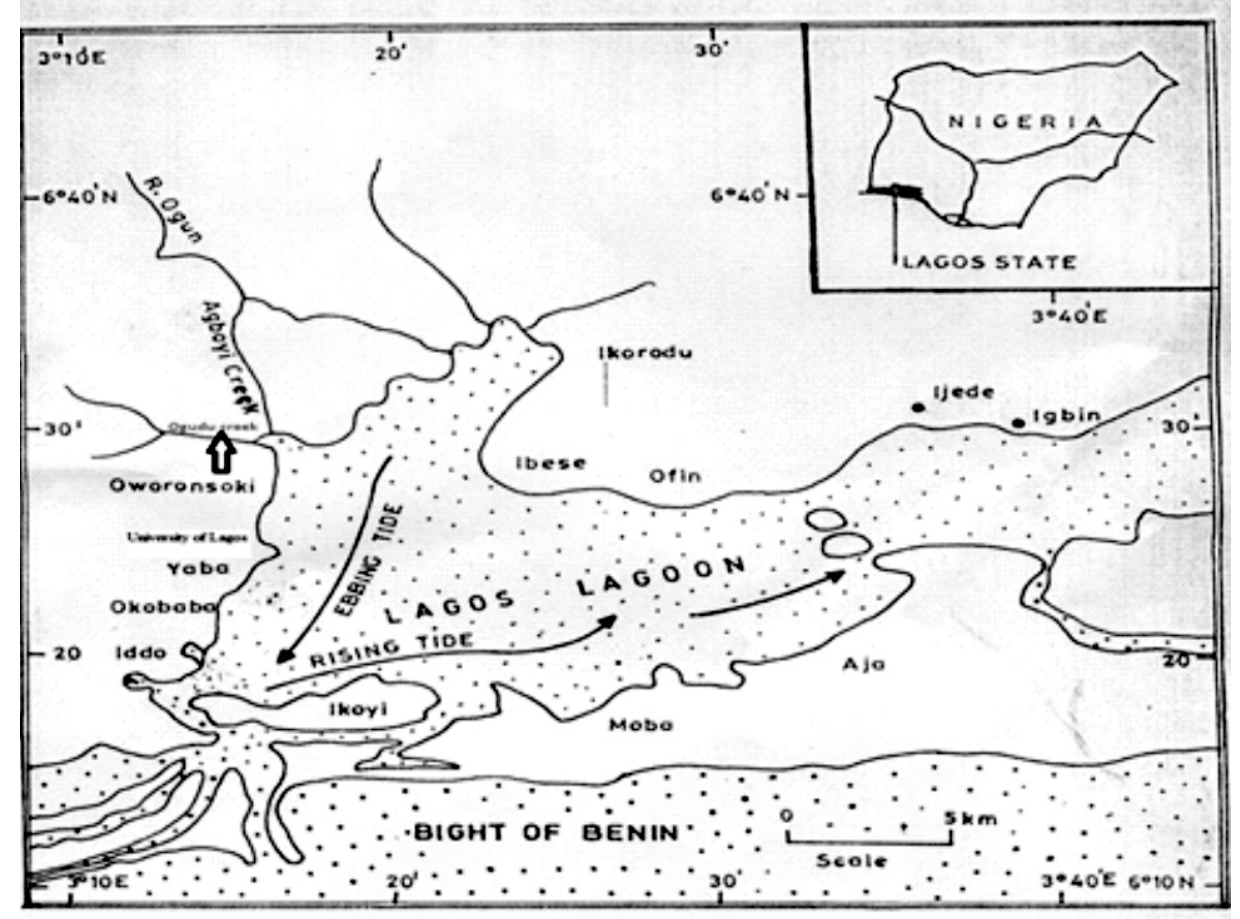

Figure 1: Lagos Lagoon map showing the Sampling Station

\section{Sample Collection}

\section{Fish Collection}

The specimens used for this study were collected between January and May 2011 from the Ogudu Creek using a cast net $(0.5 \mathrm{~mm}$ mesh size net $)$ operated along the sides of the creek between $0700 \mathrm{hr}$ and $0900 \mathrm{hr}$ every sampling day. Specimens were preserved in a freezer to prevent decomposition prior to analysis in the laboratory. In this study, combined sexes were used because the gonadal stages of the specimens were not visible to be identified. The sexual maturation of T. atlanticus is determined primarily with the length of the fish. In males it occurs between 90 and $117.5 \mathrm{~cm}$ and in females at approximately $128.5 \mathrm{~cm}$. This maturation can occur between the ages of 6 and 13 years for both sexes (Hill, 2002).

\section{Water Sample Collection}

\section{Physico-chemical Parameters}

Water samples were taken with a Niskin bottle at the depth of $0.5 \mathrm{~m}$ below the surface from January to May 2011. Once collected, all samples were stored on ice and immediately transported to the laboratory. Temperature, $\mathrm{pH}$, salinity and dissolved oxygen (DO) were measured in situ using the HI $9828 \mathrm{pH} / \mathrm{ORP} / \mathrm{EC} / \mathrm{DO}$ multiparameter Instrument (Hanna). Water transparency was also determined in situ using a Secchi disc.

\section{Laboratory Analysis of Fish Fish Measurement}

In the laboratory, fish samples were thawed in the open air in the laboratory and body wiped dry. The standard length, total length, fork length, body depth, eye size, head length, post orbital length, pre-orbital length, pectoral fin length, mouth agape were determined using a measuring board and the weight determined using a weighing balance. The length measurement was recorded in centimeters while the weight measurements were recorded in grams. The total weight of each fish was achieved by placing each Tarpon atlanticus on an electronic weighing balance and the result was recorded to the nearest decimal point in grams. The stomach was split open using a pair of dissecting scissors to determine its content.

\section{Stomach Content Analysis}

The stomach content was analyzed to establish the feeding habit of the fish. Since the fish were frozen immediately after catching, their stomach contents were representative of their last meals. The fish was dissected from the anus to the head and the alimentary canal was traced from the anus to the mouth. A sac-like structure (stomach) was 
traced along the tube. The stomach was detached from the other internal structures and placed on a Petri dish. Three drops of the mixture (stomach content) were placed on a glass slide using a dropper. The slide was covered with a cover slip and viewed under a light microscope in order to identify the various food items. This method is referred to as the numerical method (Hyslop, 1980). The total of each kind of food was recorded and expressed as a percentage of the total number of all food items as reported by Hyslop (1980).

\section{Length-weight Relationship}

The length - weight relationship of each fish was studied and represented by the equation:

$\mathrm{W}=\mathrm{a}+\mathrm{bL}$

Where:

$$
\begin{aligned}
& \mathrm{W}=\text { weight in grams } \\
& \mathrm{a}=\text { regression constant } \\
& \mathrm{b}=\text { regression coefficient } \\
& \mathrm{L}=\text { length in centimeter }(\mathrm{cm})
\end{aligned}
$$

The equation was further transformed into a linear regression equation as:

$$
\log \mathrm{W}=\quad \log \mathrm{a}+\mathrm{b} \log \mathrm{L}
$$

Scattered diagrams were plotted to illustrate the relationship between the fish length and weight of fish.

\section{Condition Factor $(\mathbf{K})$}

This shows the state (well-being) of the fish i.e. the leanness or fattiness of a fish, (Gomiero and Braga, 2005). It is calculated as:

$$
\mathrm{K}=\frac{100 \mathrm{xW}}{\mathrm{L}^{3}}
$$

Table 1: Physico-chemical Parameters of Water from the Ogudu Creek

\begin{tabular}{|l|l|l|l|l|l|l|}
\hline & January & February & March & April & May & Mean \pm SD \\
\hline Air Temperature $\left({ }^{\circ} \mathrm{C}\right)$ & 32 & 31 & 29 & 25 & 24 & $30.5 \pm 1.21$ \\
\hline $\begin{array}{l}\text { Surface water } \\
\text { temperature }\left({ }^{\circ} \mathrm{C}\right)\end{array}$ & 28.5 & 29.5 & 33.5 & 32 & 32 & $31.0 \pm 1.31$ \\
\hline $\mathrm{pH}$ & 3.97 & 5.05 & 7.2 & 7.6 & 8.3 & $6.13 \pm 0.32$ \\
\hline Salinity (\%o) & 12.8 & 17.5 & 20 & 15.2 & 24 & $18.4 \pm 5.6$ \\
\hline $\begin{array}{l}\text { Dissolved Oxygen } \\
(\mathrm{mg} / \mathrm{L})\end{array}$ & 4.8 & 8.6 & 4.3 & 5.6 & 7.48 & $6.45 \pm 1.01$ \\
\hline Transparency (cm) & 69 & 80 & 61 & 39 & 12 & $52.2 \pm 40.2$ \\
\hline
\end{tabular}

Where $\mathrm{W}=$ weight of fish in grams

$\mathrm{L}=$ length of fish in centimeters

$\mathrm{K}=$ condition factor

\section{Morphometric Analysis}

Morphometric analysis of the body parts such as the head length, total length, body depth, standard length etc. were analyzed using a scattered diagram and the regression coefficients.

\section{RESULTS}

\section{Physico-chemical Characteristics}

The lowest air temperature occurred in May, while the highest temperature occurred in January. The highest temperature was recorded in March while the lowest temperature was recorded in January; the mean surface water temperature during the sampling period was $31.0 \pm 1.31{ }^{\circ} \mathrm{C}$. The $\mathrm{pH}$ reading varied from 3.97 to 8.3 and the mean $\mathrm{pH}$ value for the sampling period was $6.13 \pm 0.32$. The salinity values during the sampling period varied. The lowest salinity $(12.80 \%$ ) was recorded in January and the highest salinity (24\%0) was recorded in May. The mean salinity value for the sampling duration was $18.4 \pm 5.6 \%$.

The dissolved oxygen values ranged between 4.3 $\mathrm{mg} / \mathrm{L}$ and $8.6 \mathrm{mg} / \mathrm{L}$. The highest value $(8.6 \mathrm{mg} / \mathrm{L})$ $(4.3 \mathrm{mg} / \mathrm{L})$ was recorded in March. The mean value of dissolved oxygen was $6.45 \pm 1.01 \mathrm{mg} / \mathrm{L}$. The physico-chemical parameters of water from the Ogudu Creek is shown in table 1. was recorded in February while the lowest value 
Emmanuel and Ross: Morphometric Characteristics, Food of Tarpon atlanticus and Water Quality Trends 005

\section{Length - frequency Distribution}

The total length of 192 specimens ranged from $6.0 \mathrm{~cm}$ to $21.9 \mathrm{~cm}$ (standard length $5.1 \mathrm{~cm}-16.0$ $\mathrm{cm})$. The Length - frequency distribution is presented in table 2. The length frequency distribution of Tarpon atlanticus showed a unimodal distribution.

\section{Length - weight Relationship}

The total lengths of Tarpon atlanticus examined in Ogudu Creek ranged from $11.0 \mathrm{~cm}$ to $25.9 \mathrm{~cm}$ while the weights ranged from $1.97 \mathrm{~g}$ to $76.93 \mathrm{~g}$. The scattered diagrams of the length - weight relationship are shown in figures 2 and 3 . The logtransformed length fitted over weight gave linear growth pattern. The combined sexes gave this relationship equation: $\log w t .=0.654+1.504 \mathrm{~L}$ with correlation coefficient value $(\mathrm{r}=0.911)$. The value of ' $b$ ' for combined sexes was 1.504 .

Table 2: Length - Frequency Distribution of Tarpon atlanticus of the Ogudu Creek.

\begin{tabular}{|l|l|l|}
\hline $\begin{array}{l}\text { Total length } \\
(\mathbf{c m})\end{array}$ & Frequency & $\begin{array}{l}\text { Percentage } \\
\text { Frequency }\end{array}$ \\
\hline $11.0-15.9$ & 143 & 74.4 \\
\hline $16.0-20.9$ & 41 & 21.4 \\
\hline $21.0-25.9$ & 8 & 4.2 \\
\hline Total & $\mathbf{1 9 2}$ & $\mathbf{1 0 0}$ \\
\hline
\end{tabular}

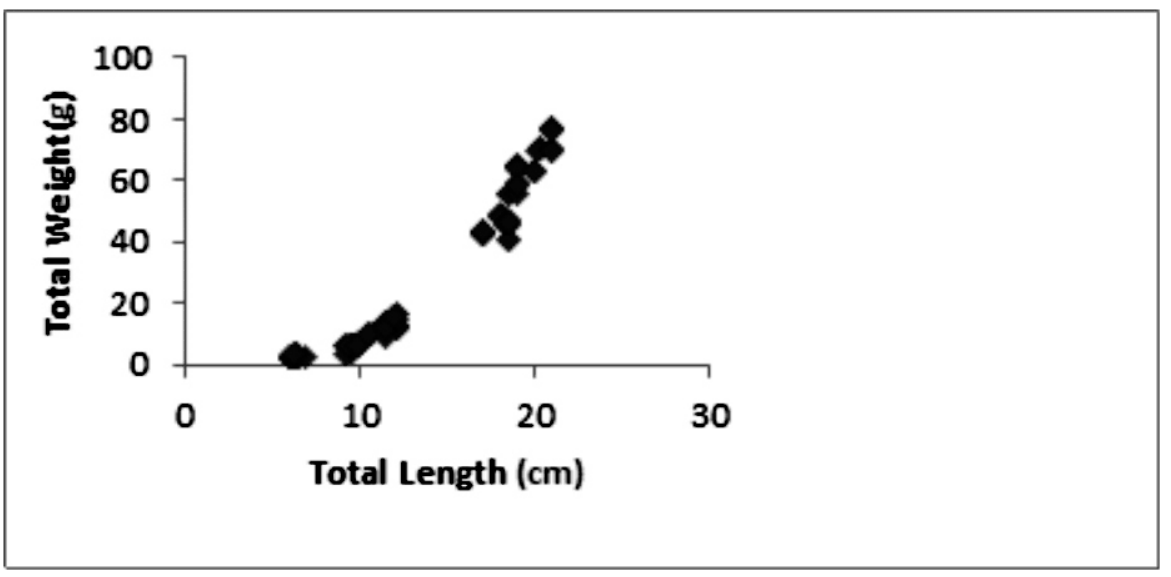

Figure 2: Length - Weight Relationship of Tarpon atlanticus in the Ogudu Creek

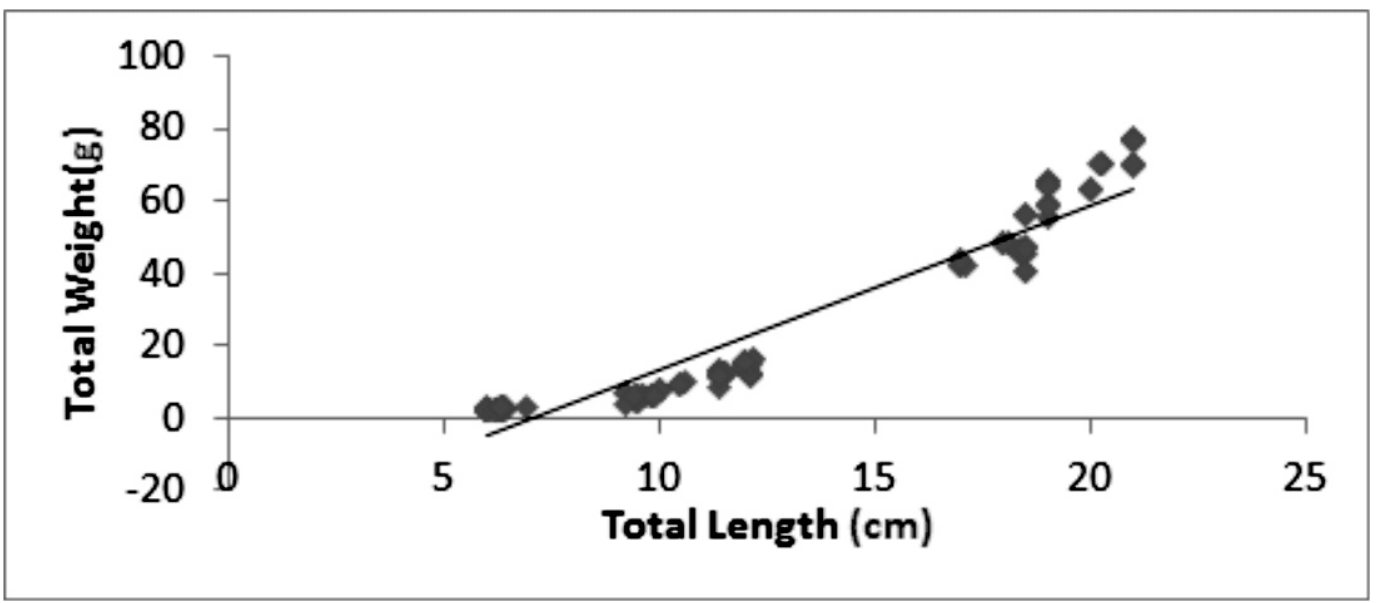

Figure 3: Length - Weight Linear Relationship of Tarpon atlanticus of the Ogudu Creek 
006 Emmanuel and Ross: Morphometric Characteristics, Food of Tarpon atlanticus and Water Quality Trends

\section{Stomach Condition}

The stomach content analyzed shows the food habit of the fish. The stomach condition and content of T. atlanticus in Ogudu Creek is shown in table 3 and 4 . Out of total 192 specimens analysed, $31.1 \%$ had empty stomach, $31.8 \%$ had their stomach filled with food. The stomach content of $T$. atlanticus in relation to percentage food composition is shown in figure 4.

Table 3: Stomach Condition of Tarpon atlanticus in the Ogudu Creek

\begin{tabular}{|l|l|l|}
\hline Condition & Frequency & Percentage \\
\hline $0 / 4$ & 60 & 31.1 \\
\hline $1 / 4$ & 26 & 13.5 \\
\hline $2 / 4$ & 61 & 31.8 \\
\hline $3 / 4$ & 22 & 11.5 \\
\hline $4 / 4$ & 23 & 11.9 \\
\hline Total & $\mathbf{1 9 2}$ & $\mathbf{1 0 0}$ \\
\hline
\end{tabular}

Table 4: Summary of the Stomach Content of T. atlanticus in Ogudu Creek.

\begin{tabular}{|l|l|l|l|l|}
\hline Food item & $\begin{array}{l}\text { Numerical } \\
\text { method }\end{array}$ & $\begin{array}{l}\text { Numerical } \\
\text { percentage }\end{array}$ & $\begin{array}{l}\text { Occurrence } \\
\text { method }\end{array}$ & $\begin{array}{l}\text { Percentage of } \\
\text { occurrence }\end{array}$ \\
\hline Fish & 93 & 54.0 & 47 & 38.2 \\
\hline Fish scale & 79 & 45.9 & 65 & 52.8 \\
\hline $\begin{array}{l}\text { Unidentified } \\
\text { mass }\end{array}$ & & & 11 & 8.94 \\
\hline Total & 172 & 100 & 123 & 100 \\
\hline
\end{tabular}

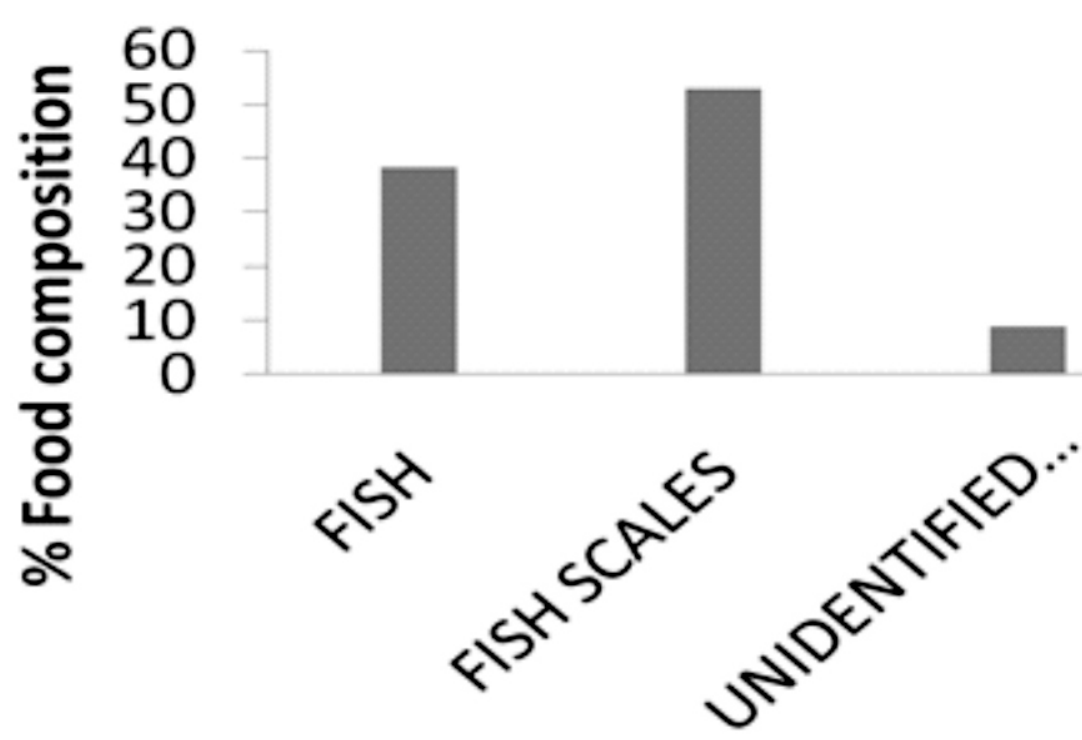

Food items

Figure 4: Stomach Content of T. atlanticus in Ogudu Creek. 


\section{Condition Factor}

The condition factor for both sexes varied from 0.658 to 0.897 . The lowest $\mathrm{K}$ value was obtained from the size group range of $21.0-25.9 \mathrm{~cm}$ and the highest $\mathrm{K}$ value was obtained from the size group range of $6.0-10.9 \mathrm{~cm}$ (Table 5).

Table 5: The Condition Factor, Range and Mean of Tarpon atlanticus in Ogudu Creek

\begin{tabular}{|l|l|l|}
\hline $\begin{array}{l}\text { Size group } \\
(\mathbf{c m})\end{array}$ & $\begin{array}{l}\text { Range of condition } \\
\text { factor }\end{array}$ & $\begin{array}{l}\text { Mean of condition } \\
\text { factor }\end{array}$ \\
\hline $6.0-10.9$ & $0.48-1.30$ & 0.90 \\
\hline $11.0-15.9$ & $0.08-0.99$ & 0.76 \\
\hline $16.0-20.9$ & $0.06-0.96$ & 0.72 \\
\hline $21.0-25.9$ & $0.08-1.05$ & 0.66 \\
\hline
\end{tabular}

\section{Morphometric Analysis}

Five months of morphometric analysis of $T$. atlanticus, exerts a highly positive correlation $(\mathrm{r}=$ 0.927) between body weight and total length. March samples exhibit a highly positive correlation of $r=0.967$ between standard length and total length. Similarly head length versus total length exhibited a highly positive correlation, $r=$ 0.78 in January. Correlation between body depth and total length was highly positive in January, $\mathrm{r}=$ 0.785. Significant positive correlation was noted between pectoral fin length versus total length in May, $r=0.72$. In March, anal fin length and total length when correlated gave a correlation coefficient of $r=0.94$.

In the morphometric analysis, all the characters assumed as $\mathrm{Y}$, show a positive correlation with total length $(\mathrm{X})$. It would indicate the growth of individual organs in relation to overall growth of the fish. But the varying significance at different levels indicates the disproportionate growth of these organs studied, when compared to total length.
Relationship between the total length parameters and body weight exhibited high level of relationship in March, moderate level in January and February and low level in April and May (Table 6i). In total length versus standard length, January, February, March, April and May show high level of relationship (Table 6 ii). There was no high level of relationship between total length and head length whereas moderate level was exhibited in January and low level by February, March, April and May (Table 6iii). No maximum level of relationship was observed in total length versus body depth but moderate level was observed in January and March and minimum level in February, April and May (Table 6 iv). Low level of relationship was shown between total length and pectoral fin length throughout the study except in January and moderate level was recorded (Table 6v). Total length and anal fin length relationship showed maximum level in January and April, moderate level in May and minimum level in February and April (Table 6 vi). 
Table 6: Summary of the Regression Analysis

\begin{tabular}{|c|c|c|c|c|c|c|}
\hline S. no & $Y$ & $\mathbf{X}$ & Months & $\mathbf{N}$ & $Y=a+b x$ & $\mathbf{R}$ \\
\hline $\bar{i}$ & $\begin{array}{l}\text { Total } \\
\text { length }\end{array}$ & $\begin{array}{l}\text { Body } \\
\text { weight }\end{array}$ & $\begin{array}{l}\text { January } \\
\text { February } \\
\text { March } \\
\text { April } \\
\text { May }\end{array}$ & 192 & $\begin{array}{l}Y=2.059+12.31 x \\
Y=8.340+101.0 x \\
Y=1.041+3.921 x \\
Y=2.782+19.46 x \\
Y=2.413+16.84 x\end{array}$ & $\begin{array}{l}0.825 \\
0.828 \\
0.927 \\
0.285 \\
0.154\end{array}$ \\
\hline ii & $\begin{array}{l}\text { Total } \\
\text { length }\end{array}$ & $\begin{array}{l}\text { Standard } \\
\text { length }\end{array}$ & $\begin{array}{l}\text { January } \\
\text { February } \\
\text { March } \\
\text { April } \\
\text { May }\end{array}$ & 192 & $\begin{array}{l}Y=0.789+0.024 x \\
Y=0.609+3.228 x \\
Y=0.677+0.857 x \\
Y=1.079+3.251 x \\
Y=1.254+4.584 x\end{array}$ & $\begin{array}{l}0.973 \\
0.928 \\
0.967 \\
0.990 \\
0.904 \\
\end{array}$ \\
\hline iii & $\begin{array}{l}\text { Total } \\
\text { length }\end{array}$ & $\begin{array}{l}\text { Head } \\
\text { length }\end{array}$ & $\begin{array}{l}\text { January } \\
\text { February } \\
\text { March } \\
\text { April } \\
\text { May }\end{array}$ & 192 & $\begin{array}{l}Y=0.147+0.680 x \\
Y=0.228+0.627 x \\
Y=0.107+1.010 x \\
Y=0.091+1.587 x \\
Y=0.021+1.911 x\end{array}$ & $\begin{array}{l}0.786 \\
0.437 \\
0.554 \\
0.000 \\
0.003 \\
\end{array}$ \\
\hline iv & $\begin{array}{l}\text { Total } \\
\text { length }\end{array}$ & Body depth & $\begin{array}{l}\text { January } \\
\text { February } \\
\text { March } \\
\text { April } \\
\text { May }\end{array}$ & 192 & $\begin{array}{l}Y=0.240+0.307 x \\
Y=0.069+3.085 x \\
Y=0.164+0.370 x \\
Y=0.211+0.093 x \\
Y=0.254+0.404 x\end{array}$ & $\begin{array}{l}0.785 \\
0.134 \\
0.690 \\
0.029 \\
0.188 \\
\end{array}$ \\
\hline $\mathrm{v}$ & $\begin{array}{l}\text { Total } \\
\text { length }\end{array}$ & $\begin{array}{l}\text { Pectoral fin } \\
\text { length }\end{array}$ & $\begin{array}{l}\text { January } \\
\text { February } \\
\text { March } \\
\text { April } \\
\text { May }\end{array}$ & 192 & $\begin{array}{l}\mathrm{Y}=0.137+0.070 \mathrm{x} \\
\mathrm{Y}=0.114+0.436 \mathrm{x} \\
\mathrm{Y}=0.038+0.649 \mathrm{x} \\
\mathrm{Y}=0.151+0.134 \mathrm{x} \\
\mathrm{Y}=0.482+3.421 \mathrm{x}\end{array}$ & $\begin{array}{l}0.707 \\
0.281 \\
0.124 \\
0.261 \\
0.720 \\
\end{array}$ \\
\hline vi & $\begin{array}{l}\text { Total } \\
\text { length }\end{array}$ & $\begin{array}{l}\text { Anal fin } \\
\text { length }\end{array}$ & $\begin{array}{l}\text { January } \\
\text { February } \\
\text { March } \\
\text { April } \\
\text { May } \\
\end{array}$ & 192 & $\begin{array}{l}\mathrm{Y}=0.154+0.026 \mathrm{x} \\
\mathrm{Y}=0.141+0.363 \mathrm{x} \\
\mathrm{Y}=0.123+0.234 \mathrm{x} \\
\mathrm{Y}=0.303+1.769 \mathrm{x} \\
\mathrm{Y}=0.273+1.187 \mathrm{x}\end{array}$ & $\begin{array}{l}0.891 \\
0.587 \\
0.945 \\
0.535 \\
0.727 \\
\end{array}$ \\
\hline
\end{tabular}

\section{DISCUSSION}

The observed variations in the physico-chemical features of the water from Ogudu Creek agreed with earlier records in Lagos lagoon (Nwankwo 1991, Solarin 1998; Ladipo et al. 2011; Lawson 2011).

The length frequency distribution of $T$. atlanticus showed that the fish exhibited unimodal distribution in the Ogudu Creek. The frequency distribution study is one of the methods used for determining age of fishes. This method has been successfully used by Fagade and Olaniyan (1972) to age the Bonga fish (Ethmalosa fimbriata) in which three age groups were reported off the Lagos coast and by Kusemiju (1976) who reported several modes in Chrysichthys walkeri in Lekki Lagoon. The total length for most of the specimens ranged between $6.0 \mathrm{~cm}$ to $21.9 \mathrm{~cm}$.

The logarithmic plot of weight against length showed a linear relationship. This relationship indicates that an increase in length leads to increase in weight. This agreed with what Kusemiju and Osibona (1998) reported in Pentanemus quinquarius off Aiyetoro Coast. The species showed a negative allometric growth.

The mean condition factor increased as the fish length increases. The condition factor values are useful in comparing the healthiness of fish from different habitats or to indicate the sustainability of the environment in which the fish are caught. Kusemiju and Osibona (1998) also reported that the mean condition factor increased as the fish length increased in P. quinquarius off Aiyetoro coast. 
The food items found in the stomach of the $T$. atlanticus indicated that the species is carnivorous. Bond (1979) reported that species in this category which include pikes and sharks are equipped with large mouths that mark them as predators for large prey which may be swallowed whole. The fullness of the stomach of this species suggests that its environment contained abundant food organisms as reported by Emmanuel (2008).

There were no distinct changes in the food preference relative to size of the fish. This disagreed with what was reported by Lawal-Are and Kusemiju (2000) and Chindah et al (2000) where they reported changes in the food items in relation to size differences in crabs. Of the 6 morphometric characters examined, all exhibited a significantly positive correlation $(p<0.01)$ among the different parts of the fish body. This showed that growth occurs in all organs of the fish but with different level of significance and these indicate that different organs grow differently in different months. The conventional approach for such analysis is based on measurement along the antero - posterior body axis and the depth measurement. In this study variation in the various morphological characters of five different months of the fishes was found. The results of the present study also explain that $T$. atlanticus living in the same place showed morphological divergence as noted by Manimegalai, et al. (2010) and this indicates the possibility for microhabitat restriction that may influence this variation. Population differentiation may occur despite extensive gene flow between fish populations and strong differential selective pressure exerted on the different fish population by local environmental factors such as temperature. It is not possible to confirm whether the observed variation is associated with environmental conditions, as the present analysis does not include environmental data for the sample localities and therefore, further environmental comparisons of these areas would be worthwhile.

\section{REFERENCES}

Anyanwu, P. E. (2004). The biology, fishery and culture potentials of the Atlantic tarpon, Tapon atlanticus (val.) in coastal waters of Western Nigeria. Ph.D. Thesis.
University of Lagos, Nigeria.

Bayagbona, E. O. (1969). Age determination and Bertalanffy growth parameters of $P$. senegalensis using "Burnt Otolith technique". Proceeding of the symposium on the oceanography and fisheries resources of tropical Atlantic. UNESCO, pp. 249-359.

Bond, C. E. (1979). Biology of fishes. W. B. Saunders Company. New York. 514pp.

Chaverri-charcon, D. (1994). Ecology and feeding of the tarpon, Megalops atlanticus. Revista de Biologia Tropical. 42 (1/2): 225-232.

Chindah, A. C, Tawari, C. C and Ifechukwude, K. A. (2000). The food and feeding habits of the swimming crab, Callinectes arenicola (portunidae) of New Calabar River, Nigeria. Journal of Applied Sciences and Environmental Management, 4: 51-57

Crabtree, R.E., Cyr, E.C. and Dean, J.M. (1995). Age and growth of tarpon, Megalops atlanticus, from south Florida waters. Fisheries Bulletin. 93(4):619-628.

Ekpo, A.E.A (1982). Length -weight relationship, food habits and fecundity of non - cichlid fishes in Lekki Lagoon, Nigeria. M.Sc. Thesis University of Lagos, Nigeria.

Emmanuel, B. E. (2008). The fishery and Bionomics of the Swimming crab, Callinectes amnicola (De Rochburne, 1883) from a tropical Lagoon and its adjacent creek, Southwest, Nigeria. Journal of Fisheries and Aquatic Sciences. 3 (2): 114-125.

Ezenwa, B.I. and Kusemiju, K. (1981). Age and growth determination of the catfish Chrysichtys nigroditatus(L). Journal of Fish. Biology. 19 (13):345-351.

Fagade, S. O. (1969). The biology of some fishes and the fisheries of the Lagos lagoon. Ph.D. Thesis. University of Lagos, Nigeria. 385pp.

Fagade S.O. (1974). Age determination in Tilapia melanotheron (Ruppell) in the Lagos lagoon, Lagos, Nigeria. In: Bagenal T.B. (Eds.), The ageing of fish. Unwin Brother's Ltd, London, UK,pp. 71-77.

Fagade, S. O. and Olaniyan, C. I. O. (1972). The biology of the West African shad 
010 Emmanuel and Ross: Morphometric Characteristics, Food of Tarpon atlanticus and Water Quality Trends

Ethmalosa fimbriata (Bowditch) in the Lagos lagoon, Nigeria. Journal Fish Biology. 4,519- 533

Fagade, S.O. and Olaniyan, C.I.O. (1973). The food and feeding interrelationship of the fishes of the Lagos Lagoon. Journal Fish Biology. 5: 205-225.

FAO (1969). Fisheries survey in the Western and Mid-Western regions of Nigeria. FAO/SF74/NIR6, FAO Rome pp. 142.

Fischer, W., Bianchi, G. and Scott, W. B (1981). FAO Species identification sheets for fishery purposes. East Central Atlantic fishing area 34, 37 (in part). Vols. 1-7 9par.var.). FAO. Rome.

Gomiero, L. M., Braga, F. M. S (2005). The condition factor of fishes from two river basins in Sao Paulo state, Southeast of Brazil. Acta Scientiarum. 27:73-78.

Hill, K. (2002). "Smithsonian Marine Station at Fort Pierce: Megalops atlanticus". Accessed October 13, 2015 at http:// www.sms.si.edu/irlspec/Megalo_atlant.h tm.

Hill, M. B. and Webb, J. E (1958). The ecology of Lagos lagoon II. The topography and physical features of the Lagos harbor and Lagos lagoon. Philosophical Transaction of Royal Society, London. 241:307-419.

Hureau, J. C. (1984). Megalopidae. Fishes of the North Eastern Atlantic and Mediterranean. UNESCO Paris. 1: 226227.

Hyslop, E.J. (1980). Stomach content analysis. A review of methods and their application. J. Fish. Biol. 17: 411-430.

Irvine, F. R. (1947). The fishes and fisheries of Gold coast. Crown Agents, London. 243pp.

Kusemiju, K. (1973). A Study of the Catfishes of Lekki Lagoon with Particular Reference to the Species Chrysichthys walkeri Bagridae. PhD Thesis. University of Lagos, Nigeria.

Kusemiju, K. (1976). Distribution, reproduction and growth of the catfish, Chrysichthys walker (Gunther), Chrysichtbys filamentosus (Boulegner) and Chrysichthys nigrodigitatus (Lacepede) in Lekki Lagoon, Nigeria. Journal of Fish
Biology. 10: 105-112.

Kusemiju, K. and Olaniyan, C.I.O. (1977). Food and feeding habits of the catfishishes Chrysichthys walkeri, Chrysichthys filamentosus and Chrysichthys nigrodigitatus in Lekki Lagoon, Nigeria. Journal Fish Biology. 10: 105-112

Kusemiju, K. and Osibona, A. (1998). Growth and fecundity of the threadfins, Pentanemus quinquarius (L) off Aiyetoro Coast, Nigeria. Journal Scientific Research Development 3:53-62.

Ladipo, M.K., Ajibola, V.O. and Oniye, S. J. (2011). Seasonal variations in physicochemical properties of water in some selected locations of the Lagos Lagoon. Science World Journal 6(4): 5-11

Lagler, K. F., Bardac, J. E. and Muller, R. R. (1962). Ichthyology. John Wiley and Sons, London. 545pp.

Lawal-Are, A.O and Kusemiju, K. (2000). Size composition, growth pattern and feeding habits of the blue crab, Callinectes amnicola (De Rochburne) in the Badagry lagoon, Nigeria. J. Sci. Res. Dev. 4: 117 126.

Lawson, E.O. (2011). Physicochemical parameters and heavy metals contents of water from the mangrove swamps of Lagos, Nigeria. Advances in Biological Research 5 (1): 8 21

Manimegalai, M., Karthikeyeni, S., Vasanth, S., Arub, G., Siva, V. and Subramanian, P. (2010). Morphometric analysis - A tool to identify the different variations in a fish species Etroplus maculatus. International Journal of Environmental Sciences. 1(4): 481 - 497.

Munro, I. S. R. (1967). The fishes of New Guinea. Department of Agriculture, Stock and Fisheries, Port Moresby, New Guinea, 650 pp

Nwankwo, D. I. (1991). Periphyton algae on fish fences "ACADJA" in a tropical open Lagoon. International Journal of Ecology and Environmental Sciences; 17: 1-10

Schneider, W. (1990). FAO species identification sheets for fishery purposes. Field guide to 
the commercial marine resources of the Gulf of Guinea. 268pp.

Solarin, B. B. (1998). The hydrobiology, fishes and fisheries of the Lagos lagoon, Nigeria. Ph.D Thesis. University of Lagos., p. 235.

Ugwumba, A. O. (1984). The biology of the ten pounder, Elops lacerta. Ph.D. Thesis, University of Lagos.268pp

Webb, J.E. (1958). The Ecology of Lagos lagoon. 1: The lagoons of the Guinea Coast. Philosophical Transaction Royal Society London. Ser B: 241-2, 83.

Whitehead, P.J.P. and Vergara, R. (1978). Megalopidae. In: FAO Species Identification Sheets for Fishery Purposes (ed. W. Fischer). Western Central Atlantic (Fishing Area 31). Vol. 3. FAO, Rome.
Whitehead, P. J. P., Bauchot, M. L., Hureau, J. C., Nielsen, J. and Tortonese, E. (1984). Fishes of the North-eastern Atlantic. UNESCO Report, Vol.1.510pp.

Zale, A.V. and Merrifield, S.G. (1989). Specific profiles: Life histories and environmental requirements of coastal fishes and invertebrates (South Florida) Ladyfish and Tarpon. U.S.F.W.S. Biol. Rep. No. 82:17pp

Zerbi, A. (1999). Ecology and biology of juveniles of two groups of fishes exploited in sport fisheries in Puerto Rico: the Snook, (Centopomus) and the Tarpon (Megalops atlanticus). Ph.D. Thesis, Universite D'Aix-Marsieille II. 